\title{
Driving a Bus in India: A Study of Indore Bus Rapid Transport System
}

\author{
Siddhartha K. RASTOGI ${ }^{\star}$
}

\author{
A R T I C L E I N F O \\ Article history: \\ Accepted November 2017 \\ Available online December 2017 \\ JEL Classification \\ H43, 018, R41, R42 \\ Keywords: \\ Bus Rapid Transport System, \\ Urban transport, Transportation \\ planning, Public policy, Public \\ management, Social cost-benefit \\ analysis
}

\begin{abstract}
A B S T R A C T
Indore is a typical tier-2 town in the central province of India, fast becoming a regional commercial hub in an economically booming state. The city has a population of over 2 million with no significant public transport. Among the multiple options available, the city started implementing a dedicated corridor based Bus Rapid Transport System (BRTS). The project was jointly mooted by the central, state, and city authorities. However, the system encountered a range of problems, including conflicts and pulls between multiple implementing agencies, delays in delivery of hardware and constructions, land acquisition and compensation, vested interests, public interest litigations, and court orders. The paper analyses the BRTS, introduced in Indore in the midst of 2013, from multiple party perspectives with an underlying search for public policy and public management insights The broad results indicate feasibility and desirability of the project; however, real problems emerge in public and public perception management.
\end{abstract}

(c) 2017 EAI. All rights reserved.

\section{Introduction}

As the city of Indore transits from a second-tier city in the backward central province of India to an emerging commercial centre of an emerging state, it is obvious to encounter the same transitory conflicts and dilemmas as the cities before Indore have had. The present paper attempts to study one such issue that the city witnessed recently. There has been no provision of public transport in the city for over two decades now, as the last system was dismantled and handed over to private operators circa 1980. The city got a golden opportunity to choose from a range of options of public transport, as the central government offered funds under Jawaharlal Nehru National Urban Renewal Mission (JNNURM).

As the chosen Bus Rapid Transport System (BRTS) took shape from a plan on paper to a reality on road between 2007 and 2013, a range of issues were encountered. The present paper analyses the BRTS, introduced in Indore in the midst of 2013, from multiple party perspectives with a focus on social-cost benefit analysis, public policy, and public management angle. Though there are some limitations and apparent scope of further research, it is believed that this study would help in guiding the BRTS implementation in other similar cities and would also provide insights for successful execution of public projects.

Rest of the paper is organized as follows. Section 2 discusses the demographics, socio-economic dynamics, urban landscape, and the condition of transportation facilities of the city of Indore and explores the multiple options available to the city and analyzes their contextual relevance along with the basic idea behind the BRTS structure and the suitability of BRTS for Indore. Section 3 analyzes Indore BRTS in detail from the perspectives of investments, administration, physical structures, operations, direct and indirect costs, revenues and other indirect benefits to various parties, and the economic rationale of the entire exercise. Section 4 discusses the multiple issues and problems encountered during and after the implementation of the first phase, along with potential solution approaches. Section 5 concludes with observations and reflections on the feasibility, desirability, and policy lessons from such projects.

\section{The city of Indore and transport option}

Since Indore is an old and well-populated city for over three centuries now, the urban planned development was neither existent nor possible without significant demolition. It is one of the major emerging cities of India, witnessing an increase in size, economic status, and an influx of immigrants. The sudden expansion in geographical limits, rise in density as well as absolute numbers of population, and regular influx of migrants and commuters is certain to lead to increased pressure on urban amenities; including already scant public transport service. The population of Indore has seen a phenomenal rise of about 33 percent between 2001 and 2011. The population in 2011 has increased to 3.276 million as compared to 2.465 in 
2001. This has resulted in the rise of population density from 633 to 841 per kilometre square for the same period (Census, 2011).

The economic growth has lead to a sudden outburst in the number of private vehicles and consequent congestion and pollution. The number and variety of vehicles plying on the city roads, commute time, wear and tear of roads, rate of accidents, dearth of parking spaces, and increased traffic pressure is already felt in the city. This is bound to rise further with the growth of Indore. In face of such expectations, the desirability of a cheap, easy, and safe mode public transport is established by the principle itself.

In face of such deteriorating conditions, the city had but few options. The city administration, in consultation with the state government, central government, planning commission, and some policy advisory groups evaluated several possible options, including metro rail, mono rail, BRTS, city bus, and diffused taxi for hire systems.

\section{Options for public transport}

BRTS can be put on the same footing as Light Rail Transit system (LRTS) in terms of speed and connectivity. However, it is much cheaper and cost effective when compared with other major public transport facilities like LRTS and metro. As a result, it is one of the most suitable options for finance trodden municipalities especially in Tier II and Tier III cities. There is a need to differentiate BRTS from traditional bus service also. Bus service is one of the oldest public transport systems, but due to mismatch of demand and supply of bus facility, it is mainly characterized by congestion and overcrowding. Thus, in most of the urban areas public has developed a negative connotation related to bus service. BRTS, on the other hand, provides faster connectivity with improved public facility. Since BRTS has air-conditioned buses running on a high frequency and a devoted corridor, they provide a better experience than the regular bus service.

BRTS is typically defined as a rapid mode of transportation that can combine the quality of rail transit and the flexibility of buses. To streamline the public transport system, BRTS has been adopted in many cities across India. However, the two major BRTS experiments in India have produced mixed results. The Delhi BRTS, which was the first BRTS in the country, has failed in many ways; whereas the Ahmedabad BRTS, after which the Indore BRTS is largely modelled, has been a roaring success so far for over 6 years now.

\section{Building a bus rapid transport system}

The BRTS for Indore was mooted and accepted in 2007. The entire BRTS plan is for 120.46 Kilometre, divided over 8 phases. The first phase of $23.8 \mathrm{kms}$ was completed in 2013 and the dry runs started in July 2013. The total cost was pegged at Rs. 868.15 crore, of which Rs. 654.95 crore would be the cost of infrastructure and Rs. 213.20 crore would be for operational and service facilities. The first phase cost was pegged at Rs. 173 crore. The initial funding came from the central government (50\%) under the Jawaharlal Nehru National Urban Renewal Mission (JNNURM) and the state government (20\%). For the remaining 30\% funding, a Special Purpose Vehicle (SPV) named Indore City Transport Services Limited (ICTSL) was created with joint resources from Indore Municipal Corporation (IMC), Indore Development Authority (IDA), and Madhya Pradesh Public Works Department (MPPWD). ICTSL owned the rights to generate revenue to fund this $30 \%$ through means of public-private partnerships leading to contracts for ticket vending, usage of GPS system, advertising, and bus operations.

It must be understood before looking at the financial analysis that financial feasibility or the lack of it shall not be the criteria for any decision on BRTS, as the social and economic benefits far outweigh the financial aspects. The following financial analysis is based upon the inputs received from AICTSL and Embarq and have been verified with the report of the divisional commissioner and general experience in other places. The two scenarios discussed are the optimistic one, where the expectations are just realized, and a pessimistic one, where only $60 \%$ of revenue is realized with very little reduction in costs. In both the cases, a conservative view is upheld, implying the estimation of costs on higher side and revenue on lower side.

\section{The demand for BRTS}

The Comprehensive Mobility Plan for Indore mentions per capita trip rate in Indore to be 1.12 for all trips including by walk for a population of about 22.9 lakhs. Of these, 0.98 trips per capita are motorized trips. This implies a total of 22 lakh motorized trips on a given weekday in the whole city of Indore. Out of this, the Bus Operations Plan from 2012 mentions 5.84 lakh trips on AB Road only. Of these, assuming similar proportion of motorized versus total trips, the number would be 5.11 lakh motorized trips. Further, about 40 per cent of this traffic is not limited to the $A B$ road corridor and nearby areas but either originates or ends in much farther areas. This traffic may not be catered to or captured by any public transport system unless that covers almost the whole city. This leaves about 3 lakh trips that can be said to be performed exclusively on the AB Road corridor or nearby areas.

A general thumb rule of public transport is that about half of its trips should be performed by the public transport for a sustainable growth. Therefore, the BRTS should carry at least 1.5 lakh trips daily. Assuming a 2 percent rise in this net traffic per annum, the full carrying capacity of the BRTS with 80 buses by end of the year 2014 (1.6 lakh trips a day) shall suffice for 2014 till 2020. It is assumed above that once BRTS 
reaches the full capacity of 80 buses, it would be static operations only; however, it is not considered if AICTSL would be able to add more buses or expand the network further. In such scenarios, the operational efficiency shall increase manifold at nominal incremental costs.

\section{Financial analysis under two scenarios}

A detailed item-wise financial analysis is given in the two tables below. Scenario 1 is optimistic scenario, whereas Scenario 2 is pessimistic scenario. Since the corridor is already built and operating for some time, the initial fixed costs are also not taken into considerations. This is in line with the basic principle of accounting, i.e. - sunk costs shall not be considered for future decisions. Further, the advertising revenue is mentioned separately but not included in the analysis. Finally, the possibility of some small earnings through penalties is not included as it remains vague and a non-major source of revenue.

\section{SCENARIO-1: Dedicated corridor with full capacity operations}

It is evident that if the BRTS is supported, forced, and permitted to operate at the full capacity, it is capable of making profits of about Rs. 19.39 crores over next 3 years. This analysis includes a service tax payment to the government at the stipulated rate but omits the secondary level of positive impacts; such as, employment generation, decongestion of roads, carbon credits, saved man-hours, and safety of women, children, and elderly etc.

The analysis also omits advertisement revenue of a minimum Rs. 1 crore per year (at present day prices only) that can be generated only from bus stops, kiosks, bus interiors, and BRTS railings. Moreover, if the advertising rights along the whole corridor are transferred to the AICTSL, then the estimated revenue from advertising would be around Rs. 5 crores per annum (Ref. Divisional Commissioners Order).

However, going by the conservative principal, the costs are taken at full and benefits are taken at minimum level possible. Despite such conservative estimates, the average net profit per month appears to be Rs. 53.88 lakhs for AICTSL. This would effectively leave the government with added tax revenues but no burden of the next corridor extension.

\section{SCENARIO-2: Shared corridor leading to underemployment of capacity}

If the BRTS is forced to share the corridor with other vehicles, this would cause more bottlenecks, longer trip-times, and higher fuel bills. This would also lead to a fall in footfall for the BRTS. These factors may lead to losses to the tune of Rs. 27.25 crores over next 3 years or Rs. 75 lakh per month. It would not be possible to recover these losses even with an optimistic figure or Rs. 5 crore for advertising revenue.

These losses would effectively mean loss of revenue to the government, a greater fuel import bill to the nation, loss of carbon credits, lesser possibilities of BRTS extension to the other parts of the city, and constant rise in traffic congestion in Indore. However, such losses are not considered under this scenario.

\section{Issues during and after the first phase}

These include the general opposition of land acquisition, construction, congestion, and conflict of interest with private operators. The list of problems began with general cynicism and went up to Public Interest Litigations (PILs), three of which were filed soon after the first phase dry runs began. The local bench of MP High Court gave several restrictive orders that slowed down the speed of the project implementation as well as created several operational hurdles. To further obstruct the operations of BRTS, the central government delayed supplying of additional buses promised earlier. This led to service delays and undercapacity on the route, giving credence to public angst. Further, revenue losses and overall planning began to go awry with each day.

The $A B$ road route was expanded in two uniform modes for BRTS operations and as a result, the said road became about 60 meters wide for the time till BRTS construction started. Although the city always had a narrow road but once BRTS lanes were erected, a popular backlash began, as people started blaming BRTS for the traffic-jams that were always there. Further, the bus tickets were considerably cheap and ranged from 5 to 15 rupees per trip. The safe, cheap, and air-conditioned trip is an obvious threat to the competitors. The competition, private shared cabs, autos, and private bus operators reacted by filing three separate PILs in the Indore bench of Madhya Pradesh High-court.

The High-court responded, in different phases as hearings progressed, by appointing two separate expert committees to give feasibility and operations reports, ordering private four-wheelers inside the dedicated corridor, ordering to construct speed-breakers inside the corridor to stop the private fourwheelers that it had allowed in first place, and by refusing to stop the parallel operators. In addition, neither of the two expert panel reports was permitted to be fully implemented. Instead, Indore BRTS was prohibited from taking several initiatives to increase the acceptability of the project, as the matter was sub judice.

\section{Concluding remarks}

It is well-understood that a private enterprise cannot sustain without sufficient profit-making. However, government is the only entity that can sustain despite loss-making. These losses are often of 
desirable nature, where a larger good of the present and future generations is involved. An efficient, safe, and low-cost public transport is one such desirable endeavor, which qualifies for undeterred governmental support irrespective of the profitability of the same. However, as shown above, BRTS remains a profitmaking, self-sustaining, and self-financing project if left in the hands of professional managers and saved from unnecessary vigilante or skeptic activism.

In a developing economy like India and an emerging city like Indore, a good public transport system is a must. The experience worldwide suggests that as cities grow, there is always a greater demand for mobility. People would prefer the cheapest, safest, and most convenient modes of mobility. In case if the government fails in providing such a desirable public transport, people would turn to private vehicles. This causes several problems, like constant rise in pressure on road network, traffic accidents, pollution, congestion, increased commute time, and loss of man-hours.

Moreover, the long-term indirect social impact is much higher and often, irreversible. For example, the rich can afford luxury of private transport but it reduces the mobility and thereby competitiveness of poorer people. It further increases the rich-poor divide in the society. Therefore, a robust public transport system is necessary for an economically and socially sustainable society. The full impact of the BRTS would be realized only after some gestation period as it is imperative for the city dwellers to change their behaviour and shift to public transport. Therefore, a non-interventionist free-hands period must be provided to the BRTS before further stock-taking.

\section{References}

1. Census (2011), Indore District: Census 2011 data, http://www.census2011.co.in/census/district/306-indore.html (as on 18 Aug 2016).

\begin{tabular}{|c|c|c|c|c|c|c|c|c|c|c|}
\hline \multicolumn{11}{|c|}{$\begin{array}{l}\text { APPENDICES: CaICUI } \\
\text { CALCULATIONS FOR SCENARIO - } 1\end{array}$} \\
\hline \multirow[b]{2}{*}{ Month } & \multirow[b]{2}{*}{ Days } & \multirow[b]{2}{*}{ Buses } & \multirow{2}{*}{$\begin{array}{c}\text { Monthly } \\
\text { ridership in } \\
\text { lakhs } \\
\text { (@2000 } \\
\text { passengers/ } \\
\text { bus) }\end{array}$} & \multirow{2}{*}{$\begin{array}{l}\text { Passeng } \\
\text { er (fare } \\
\text { box) } \\
\text { revenue }\end{array}$} & \multicolumn{5}{|c|}{ Expenditure (including service tax) } & \multirow[b]{2}{*}{ Surplus } \\
\hline & & & & & $\begin{array}{c}\text { Bus } \\
\text { Operatio } \\
\text { ns }\end{array}$ & $\begin{array}{c}\text { Ticketi } \\
\text { ng }\end{array}$ & $\begin{array}{c}\text { Traffic } \\
\text { Warde } \\
\text { ns }\end{array}$ & $\begin{array}{c}\text { Securit } \\
y\end{array}$ & Total & \\
\hline Jan-14 & 31 & 25 & 15.50 & 155.68 & 113.61 & 10.77 & 13.72 & 5.52 & 143.63 & 12.06 \\
\hline Feb-14 & 28 & 30 & 16.80 & 168.74 & 136.33 & 10.77 & 13.72 & 5.52 & 166.35 & 2.39 \\
\hline Mar-14 & 31 & 35 & 21.70 & 217.95 & 159.05 & 10.77 & 13.72 & 5.52 & 189.07 & 28.89 \\
\hline Apr-14 & 30 & 40 & 24.00 & 241.06 & 181.77 & 16.16 & 20.58 & 8.29 & 226.80 & 14.26 \\
\hline May-14 & 31 & 45 & 27.90 & 280.23 & 204.49 & 16.16 & 20.58 & 8.29 & 249.52 & 30.71 \\
\hline Jun-14 & 30 & 50 & 30.00 & 301.32 & 227.21 & 16.16 & 20.58 & 8.29 & 272.24 & 29.08 \\
\hline Jul-14 & 31 & 55 & 34.10 & 342.50 & 249.93 & 16.16 & 20.58 & 8.29 & 294.96 & 47.54 \\
\hline Aug-14 & 31 & 60 & 37.20 & 373.64 & 272.66 & 16.16 & 20.58 & 8.29 & 317.68 & 55.95 \\
\hline Sep-14 & 30 & 65 & 39.00 & 391.72 & 295.38 & 16.16 & 20.58 & 8.29 & 340.40 & 51.31 \\
\hline Oct-14 & 31 & 70 & 43.40 & 435.91 & 318.10 & 16.16 & 20.58 & 8.29 & 363.13 & 72.78 \\
\hline Nov-14 & 30 & 75 & 45.00 & 451.98 & 340.82 & 16.16 & 20.58 & 8.29 & 385.85 & 66.13 \\
\hline Dec-14 & 31 & 80 & 49.60 & 498.18 & 363.54 & 21.54 & 27.45 & 11.05 & 423.58 & 74.60 \\
\hline Jan-15 & 31 & 80 & 49.60 & 538.04 & 399.89 & 23.70 & 30.19 & 12.15 & 465.94 & 72.10 \\
\hline Feb-15 & 28 & 80 & 44.80 & 485.97 & 399.89 & 23.70 & 30.19 & 12.15 & 465.94 & 20.03 \\
\hline Mar-15 & 31 & 80 & 49.60 & 538.04 & 399.89 & 23.70 & 30.19 & 12.15 & 465.94 & 72.10 \\
\hline Apr-15 & 30 & 80 & 48.00 & 520.68 & 399.89 & 23.70 & 30.19 & 12.15 & 465.94 & 54.75 \\
\hline May-15 & 31 & 80 & 49.60 & 538.04 & 399.89 & 23.70 & 30.19 & 12.15 & 465.94 & 72.10 \\
\hline Jun-15 & 30 & 80 & 48.00 & 520.68 & 399.89 & 23.70 & 30.19 & 12.15 & 465.94 & 54.75 \\
\hline Jul-15 & 31 & 80 & 49.60 & 538.04 & 399.89 & 23.70 & 30.19 & 12.15 & 465.94 & 72.10 \\
\hline Aug-15 & 31 & 80 & 49.60 & 538.04 & 399.89 & 23.70 & 30.19 & 12.15 & 465.94 & 72.10 \\
\hline Sep-15 & 30 & 80 & 48.00 & 520.68 & 399.89 & 23.70 & 30.19 & 12.15 & 465.94 & 54.75 \\
\hline Oct-15 & 31 & 80 & 49.60 & 538.04 & 399.89 & 23.70 & 30.19 & 12.15 & 465.94 & 72.10 \\
\hline Nov-15 & 30 & 80 & 48.00 & 520.68 & 399.89 & 23.70 & 30.19 & 12.15 & 465.94 & 54.75 \\
\hline Dec-15 & 31 & 80 & 49.60 & 538.04 & 399.89 & 23.70 & 30.19 & 12.15 & 465.94 & 72.10 \\
\hline Jan-16 & 31 & 80 & 49.60 & 581.08 & 439.88 & 26.07 & 33.21 & 13.37 & 512.53 & 68.55 \\
\hline Feb-16 & 29 & 80 & 46.40 & 543.59 & 439.88 & 26.07 & 33.21 & 13.37 & 512.53 & 31.06 \\
\hline Mar-16 & 31 & 80 & 49.60 & 581.08 & 439.88 & 26.07 & 33.21 & 13.37 & 512.53 & 68.55 \\
\hline Apr-16 & 30 & 80 & 48.00 & 562.34 & 439.88 & 26.07 & 33.21 & 13.37 & 512.53 & 49.81 \\
\hline May-16 & 31 & 80 & 49.60 & 581.08 & 439.88 & 26.07 & 33.21 & 13.37 & 512.53 & 68.55 \\
\hline Jun-16 & 30 & 80 & 48.00 & 562.34 & 439.88 & 26.07 & 33.21 & 13.37 & 512.53 & 49.81 \\
\hline Jul-16 & 31 & 80 & 49.60 & 581.08 & 439.88 & 26.07 & 33.21 & 13.37 & 512.53 & 68.55 \\
\hline Aug-16 & 31 & 80 & 49.60 & 581.08 & 439.88 & 26.07 & 33.21 & 13.37 & 512.53 & 68.55 \\
\hline Sep-16 & 30 & 80 & 48.00 & 562.34 & 439.88 & 26.07 & 33.21 & 13.37 & 512.53 & 49.81 \\
\hline Oct-16 & 31 & 80 & 49.60 & 581.08 & 439.88 & 26.07 & 33.21 & 13.37 & 512.53 & 68.55 \\
\hline Nov-16 & 30 & 80 & 48.00 & 562.34 & 439.88 & 26.07 & 33.21 & 13.37 & 512.53 & 49.81 \\
\hline Dec-16 & 31 & 80 & 49.60 & 581.08 & 439.88 & 26.07 & 33.21 & 13.37 & 512.53 & 68.55 \\
\hline
\end{tabular}




\begin{tabular}{|l|l|r|l|}
\hline \multicolumn{4}{|c|}{ ASSUMPTIONS FOR SCENARIO - 1 } \\
\hline $\mathbf{1}$ & Average Fare & 9.30 & INR (as per existing data) \\
\hline $\mathbf{2}$ & \multicolumn{2}{|l|}{ Expenditure on ticketing, traffic wardens, and security stay at same level as Sep 2013 } \\
\hline $\mathbf{3}$ & Average ridership / bus / day & 2000 & \\
\hline $\mathbf{4}$ & Service Tax & $12.36 \%$ & Assumed to be uniform \\
\hline $\mathbf{5}$ & Annual inflation & $10 \%$ & \\
\hline $\mathbf{6}$ & Annual revenue (fare box) Hike & $8 \%$ & Assumed to be less than cost increase \\
\hline \multirow{2}{*}{$\mathbf{2}$} & Manpower increase & $50 \%$ & Added after 40 buses \\
\cline { 2 - 4 } & & $100 \%$ & Added after 80 buses \\
\hline
\end{tabular}

\begin{tabular}{|c|c|c|c|c|c|c|c|c|c|c|}
\hline \multicolumn{11}{|c|}{ CALCULATIONS FOR SCENARIO - 2} \\
\hline \multirow[b]{2}{*}{ Month } & \multirow[b]{2}{*}{$\begin{array}{c}\text { No. } \\
\text { of } \\
\text { days }\end{array}$} & \multirow[b]{2}{*}{$\begin{array}{l}\text { Numb } \\
\text { er of } \\
\text { buses }\end{array}$} & \multirow{2}{*}{$\begin{array}{c}\text { Monthly } \\
\text { ridership } \\
\text { (@ 1200 } \\
\text { passenger } \\
\text { s / bus) } \\
\end{array}$} & \multirow[b]{2}{*}{$\begin{array}{c}\text { Passenger } \\
\text { (fare box) } \\
\text { revenue }\end{array}$} & \multicolumn{5}{|c|}{$\begin{array}{l}\text { Expenditure (including service tax) } \\
\end{array}$} & \multirow[b]{2}{*}{$\begin{array}{c}\text { Surplu } \\
\mathbf{s}\end{array}$} \\
\hline & & & & & $\begin{array}{c}\text { Bus } \\
\text { Operati } \\
\text { ons }\end{array}$ & Ticketing & $\begin{array}{c}\text { Traffic } \\
\text { Warden } \\
\text { s }\end{array}$ & Security & Total & \\
\hline Jan-14 & 31 & 25 & 9.30 & 93.41 & 94.67 & 10.77 & 13.72 & 5.52 & 124.69 & -31.28 \\
\hline Feb-14 & 28 & 30 & 10.08 & 101.24 & 113.61 & 10.77 & 13.72 & 5.52 & 143.63 & -42.38 \\
\hline Mar-14 & 31 & 35 & 13.02 & 130.77 & 132.54 & 10.77 & 13.72 & 5.52 & 162.56 & -31.79 \\
\hline Apr-14 & 30 & 40 & 14.40 & 144.63 & 151.48 & 16.16 & 20.58 & 8.29 & 196.50 & -51.87 \\
\hline May-14 & 31 & 45 & 16.74 & 168.14 & 170.41 & 16.16 & 20.58 & 8.29 & 215.44 & -47.30 \\
\hline Jun-14 & 30 & 50 & 18.00 & 180.79 & 189.34 & 16.16 & 20.58 & 8.29 & 234.37 & -53.58 \\
\hline Jul-14 & 31 & 55 & 20.46 & 205.50 & 208.28 & 16.16 & 20.58 & 8.29 & 253.31 & -47.81 \\
\hline Aug-14 & 31 & 60 & 22.32 & 224.18 & 227.21 & 16.16 & 20.58 & 8.29 & 272.24 & -48.06 \\
\hline Sep-14 & 30 & 65 & 23.40 & 235.03 & 246.15 & 16.16 & 20.58 & 8.29 & 291.18 & -56.15 \\
\hline Oct-14 & 31 & 70 & 26.04 & 261.55 & 265.08 & 16.16 & 20.58 & 8.29 & 310.11 & -48.56 \\
\hline Nov-14 & 30 & 75 & 27.00 & 271.19 & 284.02 & 16.16 & 20.58 & 8.29 & 329.04 & -57.86 \\
\hline Dec-14 & 31 & 80 & 29.76 & 298.91 & 302.95 & 21.54 & 27.45 & 11.05 & 362.99 & -64.08 \\
\hline Jan-15 & 31 & 80 & 29.76 & 322.82 & 333.25 & 23.70 & 30.19 & 12.15 & 399.29 & -76.46 \\
\hline Feb-15 & 28 & 80 & 26.88 & 291.58 & 333.25 & 23.70 & 30.19 & 12.15 & 399.29 & 107.71 \\
\hline Mar-15 & 31 & 80 & 29.76 & 322.82 & 333.25 & 23.70 & 30.19 & 12.15 & 399.29 & -76.46 \\
\hline Apr-15 & 30 & 80 & 28.80 & 312.41 & 333.25 & 23.70 & 30.19 & 12.15 & 399.29 & -86.88 \\
\hline May-15 & 31 & 80 & 29.76 & 322.82 & 333.25 & 23.70 & 30.19 & 12.15 & 399.29 & -76.46 \\
\hline Jun-15 & 30 & 80 & 28.80 & 312.41 & 333.25 & 23.70 & 30.19 & 12.15 & 399.29 & -86.88 \\
\hline Jul-15 & 31 & 80 & 29.76 & 322.82 & 333.25 & 23.70 & 30.19 & 12.15 & 399.29 & -76.46 \\
\hline Aug-15 & 31 & 80 & 29.76 & 322.82 & 333.25 & 23.70 & 30.19 & 12.15 & 399.29 & -76.46 \\
\hline Sep-15 & 30 & 80 & 28.80 & 312.41 & 333.25 & 23.70 & 30.19 & 12.15 & 399.29 & -86.88 \\
\hline Oct-15 & 31 & 80 & 29.76 & 322.82 & 333.25 & 23.70 & 30.19 & 12.15 & 399.29 & -76.46 \\
\hline Nov-15 & 30 & 80 & 28.80 & 312.41 & 333.25 & 23.70 & 30.19 & 12.15 & 399.29 & -86.88 \\
\hline Dec-15 & 31 & 80 & 29.76 & 322.82 & 333.25 & 23.70 & 30.19 & 12.15 & 399.29 & -76.46 \\
\hline Jan-16 & 31 & 80 & 29.76 & 348.65 & 366.57 & 26.07 & 33.21 & 13.37 & 439.22 & -90.57 \\
\hline Feb-16 & 29 & 80 & 27.84 & 326.15 & 366.57 & 26.07 & 33.21 & 13.37 & 439.22 & 113.06 \\
\hline Mar-16 & 31 & 80 & 29.76 & 348.65 & 366.57 & 26.07 & 33.21 & 13.37 & 439.22 & -90.57 \\
\hline Apr-16 & 30 & 80 & 28.80 & 337.40 & 366.57 & 26.07 & 33.21 & 13.37 & 439.22 & 101.81 \\
\hline May-16 & 31 & 80 & 29.76 & 348.65 & 366.57 & 26.07 & 33.21 & 13.37 & 439.22 & -90.57 \\
\hline Jun-16 & 30 & 80 & 28.80 & 337.40 & 366.57 & 26.07 & 33.21 & 13.37 & 439.22 & $101.81^{-}$ \\
\hline Jul-16 & 31 & 80 & 29.76 & 348.65 & 366.57 & 26.07 & 33.21 & 13.37 & 439.22 & -90.57 \\
\hline Aug-16 & 31 & 80 & 29.76 & 348.65 & 366.57 & 26.07 & 33.21 & 13.37 & 439.22 & -90.57 \\
\hline Sep-16 & 30 & 80 & 28.80 & 337.40 & 366.57 & 26.07 & 33.21 & 13.37 & 439.22 & 101.81 \\
\hline Oct-16 & 31 & 80 & 29.76 & 348.65 & 366.57 & 26.07 & 33.21 & 13.37 & 439.22 & -90.57 \\
\hline Nov-16 & 30 & 80 & 28.80 & 337.40 & 366.57 & 26.07 & 33.21 & 13.37 & 439.22 & 101.81 \\
\hline Dec-16 & 31 & 80 & 29.76 & 348.65 & 366.57 & 26.07 & 33.21 & 13.37 & 439.22 & -90.57 \\
\hline
\end{tabular}




\begin{tabular}{|c|c|c|c|}
\hline \multicolumn{4}{|c|}{ ASSUMPTIONS FOR SCENARIO - 2} \\
\hline 1 & Average Fare & 9.30 & INR (as per existing data) \\
\hline 2 & \multicolumn{3}{|c|}{ Expenditure on ticketing, traffic wardens, and security stay at same level as Sep 2013} \\
\hline 3 & $\begin{array}{l}\text { Average ridership per bus per } \\
\text { day }\end{array}$ & 1200 & \\
\hline 4 & Service Tax & $12.36 \%$ & Assumed to be uniform \\
\hline 5 & Annual inflation & $10 \%$ & \\
\hline 6 & $\begin{array}{l}\text { Annual revenue (fare box) } \\
\text { increase }\end{array}$ & $8 \%$ & Assumed to be less than cost increase \\
\hline \multirow{2}{*}{7} & \multirow{2}{*}{ Manpower requirement increase } & $50 \%$ & Added after 40 buses \\
\hline & & $100 \%$ & Added after 80 buses \\
\hline 8 & Decrease in operated kilometres & $17 \%$ & $\begin{array}{r}\text { Each bus was operating approx. 240km until Sep 2013, as against } \\
200 \mathrm{~km} \text { since Oct } 2013 .\end{array}$ \\
\hline
\end{tabular}

